IRA-International Journal of Management \& Social Sciences

ISSN 2455-2267; Vol.06, Issue 02 (2017)

Pg. no. 264-267

Institute of Research Advances

https://research-advances.org/index.php/RAJMSS

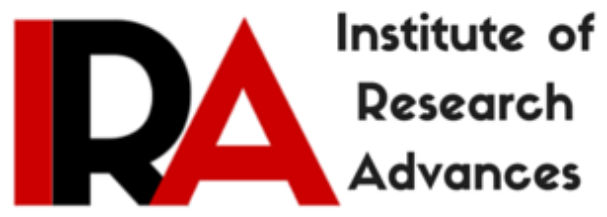

\title{
Impact of Technology on Consumer Behaviour
}

\section{Julie Jose}

Research Scholar, St.Albert's College, Ernakulam, India.

Type of Review: Peer Reviewed.

DOI: http://dx.doi.org/10.21013/jmss.v6.n2.p10

\section{How to cite this paper:}

Jose, J. (2017). Impact of Technology on Consumer Behaviour. IRA-International Journal of Management \& Social Sciences (ISSN 2455-2267), 6(2), 264-267. doi:http://dx.doi.org/10.21013/jmss.v6.n2.p10

(C) Institute of Research Advances

\section{(c)) EY-NC}

This work is licensed under a Creative Commons Attribution-Non Commercial 4.0 International License subject to proper citation to the publication source of the work.

Disclaimer: The scholarly papers as reviewed and published by the Institute of Research Advances (IRA) are the views and opinions of their respective authors and are not the views or opinions of the IRA. The IRA disclaims of any harm or loss caused due to the published content to any party. 


\begin{abstract}
With the emergence of technological development, companies have to change its outlook towards consumers. We can't compare the situation today with 10 or 15 years back. Connecting consumer is now easier than before. With the invent of more devices like iPod, tablets etc. helped both the seller and the buyer to make their goals come true very soon. With the arrival of new devices the old one becomes obsolete and people have to adjust with new one created some burden on the users. Still these devices improved the standard of living of the people to a great extend.
\end{abstract}

KEY WORDS: Consumer, Consumer Behaviour, Technological Developments

\title{
CONSUMER BEHAVIOUR
}

Consumer behavior is the decision making of people in spending their available resources like time, money and effort on consumption related items. Consumer behavior is affected by many factors like cultural factors, economic factors, psychological factors, personal factors, and technological factors. In this article the influence of technological factors on consumer behavior is emphasized.

\section{ROLE OF TECHNOLOGY}

The journey of change from conventional devices to modern devices with super speed data helped the marketer to reach consumers of all ages and satisfy their needs. With the help of technology marketer can be connected with the consumer whether the consumers are online or offline. Technology makes the whole world a one community and that helped the company to reach all consumers easily and quickly.

In olden times, if a consumer wants to buy a product, he needs to reach shop within the working hours of that shop. Otherwise he won't be able to buy that product. But with the emergence of e-commerce, customers can buy products at any time. If they want to buy a product or get any information about the product, he can get it at another time. Now, every consumer knows that he is the king of the market and that have much more power than the marketer. Consumers level of expectation is also changed a lot when these is smart devices got a place in our life. So all business should be careful in updating with the changes, or they will be thrown out of market.

The attitude of marketer is greatly influenced by social media. Customer services were provided by companies through emails and phone calls. But with the popularity of social medias and live chats, if an enquiry from a customer is not answered within seconds, the brand reputation of the company will be affected and there is no place for the company in the minds of whole world.

In short, with technology consumers are more connected, their expectations become high and more sophisticated tools are being used for getting the needs satisfied.

\section{TECHNOLOGY-STAGES OF TRANSITION}

About a century ago, no one could even imagine shopping from home through internet or virtual stores. But, now it became a reality.

\section{PRE-1800s: TRADITIONAL SHOPS}

Barter system was common in this era. Goods produced at one place is sold locally and transported to far away places. Most of the retail business is done in small scale as a family owned establishment.

\section{0s: THE BIRTH OF DEPARTMENT STORES}


During this era, the transportation system became more popular and effective. As it is less costly, people began to use this mode for transporting goods to distant places. Then the retail sector began to grow. The largest retail store "Marble Palace" was built by Alexander Stewart in 1846. It became the first department store and later it influenced others to develop stores in this design. The introduction of small paper roll recording each transaction resulted in first "sales receipts".

Later, this became inevitable for doing any business. Then department stores began to flourish in our country.

\section{LATE 1800s-MID 1900s: MAIL ORDER AND CATELOGUES}

This is a period of boom for mail order business. During this period, Catalogues became popular. Mail order catalogues specifying name of product and price helped to keep a record for sending goods to long distance.

\section{0s: BABY BOOM}

After the Second World War, a population explosion known as "baby-boom" increased the consumer demand. As a result, new highways, shopping centers etc. were emerged. Then the first credit card program is launched in America 1958. In 1960 the debit card is invented. In 1962, discount stores like Walmart, Target etc. were opened.

\section{LATE 1900s: THE ERA OF BIG BOX STORES}

With the emergence of large bulk item stores, department store faces a decline in their business. Big box store chains got a place in the minds of consumers as they can purchase all items at one location. Walmart became largest retail store. Amazon.com became very active, selling goods online through internet.

\section{0s-NOW: THE INTERNET AGE}

During the internet age, many retail shops and department stores came to an end. They close the doors as the consumer turned to online shopping from their homes. Amazon became the largest online retailer. In 2006 Face book debuted, and companies could promote themselves on social network. In 2008, Apple and iTunes, became the largest music retailer in the world. The technology paved way to calculate myriad transactions in seconds.

\section{TRENDS OF INNOVATION}

In order to survive, a business needs to customize its products. Consumers are voting again and again (through their purchases) for devices they offer peace of mind and anticipate their needs.

They offer convenience and peace of mind to consumers". Following are some of the innovative trends shown impact on consumer behavior:

\section{SMART PHONES}

Out of 5 billion people who are using mobile phones, 1.08 billion people are smart phone users. People prefer smart phones than normal mobile phone because of the multi-function utilities of smart phones. They can be used for the purpose of gaming, apps, mobile advertising and social networking.

There is a direct impact between increasing demand of smart phone and purchase pattern of consumers. Smartphone increases the convenience of users as it helps for e-mail, chat, shopping etc. Smart phones work as a useful shopping aid, for instance, getting instant shopping, scanning product bar code etc. 


\section{SOCIAL MEDIA}

Social media is a platform for communication both for consumers and sellers. Consumers seek advice on making purchase whether consumer durable or service through social networking sites like Face book and Google. Similarly many companies are using them to influence consumer opinions and buying patterns.

\section{ONLINE EDUCATION}

Many students are moving from traditional method of learning to E-learning. Online segment is categorized into different sub-segments such as K-12 learning, Higher Ed learning and Corporate E learning. Online education helps the students to get access of highly qualified professors across different geographical regions.

\section{MOBILE PAYMENTS}

Now days, consumers are making payment online. Mobile payment facilitates transfer of money through mobile phone. It can be made through premium SMS, Direct mobile billing, Mobile web payments, and contactless NFC (Near Field Communications).

\section{MOBILE APPS}

Mobile apps can greatly influence the consumer behavior. Now a days, mobile apps are widely use in every industry like banking, consumer goods, manufacturing, media \& entertainment, pharmaceuticals, travel and hospitality.

\section{CONCLUSION}

Technology is a powerful tool in influencing and changing consumer behavior. Unless, companies go along with technology, they will be thrown out of market. It is expected that consumer behavior, over a period of time may be completely influenced by an information that is primarily processed through the internet. In a world where new technologies are emerging all the time, those companies who satisfy consumer needs first will survive and win.

\section{REFERENCES:}

1. Consumer Behaviour-An Indian Perspective, Agarwal \& Kumar

2. Www.linkedin.com

3. www.ibef.in

4. www.cagr.com 